\title{
Kant's Cosmopolitan Law: World Citizenship for a Global Order
}

\author{
PAULINE KLEINGELD \\ Washington University, St Louis
}

In debates over the conditions for a just world order, one hears frequent appeals to Kant's call for states to unite in a federation. ${ }^{1}$ Given the force of Kant's arguments and their influence on the shape of such institutions as the League of Nations and the United Nations, this is certainly justified. But an essential part of what Kant saw as necessary for a global legal order is usually neglected. What is overlooked is Kant's emphasis on the status of individuals under what he calls 'cosmopolitan law'. ${ }^{2}$ Cosmopolitan law is concerned not with the interaction between states, but with the status of individuals in their dealings with states of which they are not citizens. Moreover, it is concerned with the status of individuals as human beings, rather than as citizens of states. In Kant's political theory, cosmopolitan law (Weltbiargerrecht) is the third category of public law, in addition to constitutional law and international law. ${ }^{3}$ Its core is what Kant calls a right to hospitality. He argues that states and individuals have the right to attempt to establish relations with other states and their citizens, but not a right to enter foreign territory. States have the right to refuse visitors, but not violently, and not if it leads to their destruction. This implies an obligation to refrain from imperialist intrusions and to provide safe haven for refugees.

Kant's concept of cosmopolitan law merits all the more attention because it illuminates recent changes in the status of individuals under international law. This status has been strengthened significantly in this century, but the importance of the development has not been sufficiently recognized in political theory.

In this essay, I argue that Kant's concept of cosmopolitan law not only represents a more important part of Kant's political theory than is usually acknowledged but also provides an interesting Kantian 
grounding for several twentieth-century developments in international law. I first discuss Kant's view as to the addressees, content, and justification of cosmopolitan law. I subsequently focus on the problem of its institutionalization. I argue that despite problems with how he works it out, Kant's idea of reserving theoretical space for a third level of public law in addition to constitutional and international law is sound. Moreover, it can be developed into a position that is relevant to contemporary issues. ${ }^{4}$

One might wonder why Kant's concept of cosmopolitan law has been neglected for so long. In the literature, Kant's ideas about international law and the league of nations have always received much more attention than what he has to say about cosmopolitan law. This is also true of the current wave of writings on Perpetual Peace. I think this neglect can be explained by several factors. On the one hand, the scope of cosmopolitan law seems to be rather limited. In Perpetual Peace, where Kant introduces it, it appears in a prominent position, as the third definitive article. Compared to the weighty first and second articles, however, it seems almost negligible, or even a mere part of the second. It certainly does not seem to deserve the same amount of attention as the other two articles. ${ }^{s}$

At a superficial level, moreover, what Kant says about cosmopolitan law seems rather obvious today. Few would dispute that states should not treat visiting foreigners hostilely, or that one should have the right to travel and to attempt to establish international communication, be it commercial, cultural, or political, without having the right to enter or settle in the territory of others without their consent. In the times of slave trade, colonization, and highwaymen, these may have been controversial claims. And until the early twentieth century, Kant was regularly criticized for failing to adequately recognize the so-called 'cultural mission' of European states vis-à-vis 'savages'. ${ }^{6}$ But at the end of this century, we seem to take Kant's claims about the content of cosmopolitan law for granted.

Finally, a more philosophical reason for its neglect may be the conviction that the concept of cosmopolitan law faces the following fatal dilemma: Either it is a superfluous category, and its content can simply be subsumed under international law; or, if it is to be a distinct category, it cannot be institutionalized without presupposing the kind of world republicanism that Kant rejects. In order to show the relevance of Kant's notion of cosmopolitan law, it is necessary to show that this is a false dilemma. I shall argue that the distinction 
between international and cosmopolitan law can be defended and that the latter can be institutionalized, at least to a degree, without embracing the ideal of a single world republic. In the course of this discussion it will also become clear that Kant's conception of cosmopolitan law is by no means an insignificant appendage. Indeed, it is decidedly relevant to recent developments in international law.

\section{Kant's Cosmopolitan Law: Its Addressees, Content and Justification}

\section{Addressees}

As early as 1800 , Wilhelm Traugott Krug formulated the following abjection:

Cosmopolitan law, which people have recently introduced as a distinct part of public law, is really only a part of international law, or rather one single problem of the latter, a problem that is important enough, but that does not deserve to be listed under a title of its own, as if it were a separate part. ${ }^{\top}$

At first sight, Krug seems to have a point. After all, it. is states, not individuals, who make treaties regarding ambassadors, trade agreements, and the like. It seems that international interaction falls under international law and that nothing warrants inventing a new sphere of public law.

For Kant, however, the answer lies in the difference in addressees between international and cosmopolitan law. According to the traditional view, shared by Kant, international law is the law between states. By contrast, in cosmopolitan Jaw, 'individuals and states, who stand in an external relationship of mutual influence, are regarded as citizens of a universal state of humankind (allgemeiner Menschenstaat) (ius cosmopoliticum)' (PP 8: 349n.). ${ }^{8}$ In the Metaphysics of Morals, Kant mentions nations and 'citizens of the earth' (Erdbürger) (MM 6: 353) as bearers of cosmopolitan rights. ${ }^{9}$ Thus cosmopolitan law addresses states and individuals, addressing individuals as 'citizens of the earth' rather than as citizens of a particular state. Independently of their nationality, all humans are world citizens. ${ }^{10}$

This answers Krug's objection and warrants drawing a distinction between international law and cosmopolitan law, at least as long as 
one conceives of international law as law between states, which is how it has traditionally been conceived. Before addressing the problem of the institutionalization of cosmopolitan law, I must say more about its contents and Kant's justification.

\section{Content}

Cosmopolitan law is concerned with interaction (Verkehr) across borders. It covers any kind of communication, interaction, trade, or business. It applies to travel, migration, intellectual exchange, as well as to commercial endeavours. ${ }^{11}$

The content of cosmopolitan law is the right to hospitality: 'Cosmopolitan law shall be limited to the conditions of universal hospitality' (PP 8: 357). Kant employs a minimal and negative concept of hospitality, as 'the right of a stranger not to be treated with hostility because of his arrival on someone else's soil' (PP 8: 358). It is merely a right to visit, which Kant understands as the right to present oneself and to try to establish contacts with people and states in other parts of the world. Thus, despite the term 'hospitality right', it is emphatically not a right to be treated as a guest. A state has the right to deny a visit, as long as it does so non-violently. And individuals have the right to present themselves, not the right actually to visit with others, since the others are free to decline the request ( $M M$ 6: 352). As Kant puts it in Perpetual Peace: it is a right to 'approach', not to 'entry' (Zugang not Eingang) (PP 8: 359). Visitors do not have a general right to be supported, to be taken in, or to be tolerated by a foreign state any longer than it takes them to turn around and leave. National sovereignty sets limits to the travelling world citizen. ${ }^{12}$ Finally, no one has a right to settle on the soil of another people; this right can only be established through a treaty. Kant's targets are obvious: much of his treatment of cosmopolitan law is a strong critique of colonialism.

Incidentally, the fact that Kant mentions that one can only settle in land already occupied or used through a treaty is interesting given the intellectual climate of the time. Kant stands out amidst eighteenthcentury philosophers who discuss the question whether one needed to or even could have, treaties with people who had not yet formed a state, and whether 'savages' are capable of forming treaties in the first place. Kant here not only grounds his different view in his theory of property rights, which, in contrast to Lockean approaches, allows him to say that nomads have a rightful claim to land. He also affirms that 
anyone, whether Brit or 'Hottentot', is the potential subject of covenants, and the bearer of certain basic rights. ${ }^{13}$

Limiting its content to hospitality rights seems to make cosmopolitan law very limited indeed. But it has broader implications than one expects at first. Whether or not he intends it, Kant does defend a right that under certain circumstances is even broader than a right to political asylum, including protection from starvation or fatal disease. He argues that a state may refuse a visitor only 'when it can happen without his destruction' (Untergang, PP $8: 358$ ). This principle has significant implications. When refusing a person at the border is inpossible without the person being killed, admission is obligatory. And one cannot legitimately send a person back to a country where she or he will die or be killed as a tesult of being sent back. Kant draws this implication himself in a draft for Perpetual Peace, mentioning that people who are forced by circumstances outside their control to arrive on another state's territory should be allowed to stay at least until the circumstances are favourable for their return. He gives the examples of shipwreck victims washed ashore and of sailors on a ship seeking refuge from a storm in a foreign harbour, thus in effect stating that casmopolitan law implies the right to a safe haven $\{23: 173\}$. Kant here anticipates many of the refugee rights that were established in the twentieth century. ${ }^{14}$

Kant's view that states bave the right to reject visitors for any reason unless it causes their destruction raises the question of whether this does not make cosmopolitan law too restrictive. For example, would it be permissible for a state to turn away requests for political asylum on the grounds that, if returned, the applicant faces torture or imprisonment but not a certain death? And are states free to reject foreigners on racist grounds? Kant himself does not address these issues, but they are clearly issues that must be addressed in a defence of his notion of cosmopolitan law. In discussing this lacuna in Kant's account, it is important to emphasize that he was primarily concerned with limiting the rights of colonialist aggressors. Foremost on his mind were European states bent on taking possession of land overseas without any regard for the claims of the native population. In limiting foreigners' claims to access, he is aiming to support the sovereignty of indigenous peoples against unwanted European encroachment.

Kant could, however, easily have anticipated today's questions tegarding the precise scope of refugee rights. The eighteenth century was familiar enough with the phenomenon of refugees, and the 
treatment of some groups of refugees, for example jews, often did not meet Kant's standard. But on the basis of what Kant says about cosmopolitan law, it is possible to develop an answer to the questions posed above. Two points are central here. First, Kant's term Untergang, rendered as 'destruction', could be interpreted more broadly than referring to death only. It could conceivably also include mental destruction or incapacitating physical harm, in which case the range of cases to which it applies would be much greater. Second, Kant's theory of cosmopolitan law has some room for limits on the range of legitimate reasons for rejection. It would seem that discriminatory rules that keep groups of foreigners out by law just because they have a certain skin colour disregard these foreigners' right to present themselves and to try to establish contact. If they will be rejected a priori, regardless of who they are or what they have to offer or ask, their right to attempt to establish contact is empty.

This should not be taken to imply that states are not allowed to make any laws that exclude certain categories of foreigners from entering. Kant himself supports the Chinese and Japanese in their attempt to keep European traders at a distance. What Kant would need here is a distinction between legitimate and illegitimate reasons for keeping certain groups out. Arguably, such a discinction could be drawn in terms of whether or not the exclusionary law or policy respects the rights of others, and whether its criteria are related to the actions and proposals of the foreigner rather than being based on an arbitrary, irrelevant characteristic. For example, a law that discriminates on the basis of skin colour would be illegitimate, while a law that forbids persons from entering the country to sell opium would not. While opium salespersons should be allowed to request entry, it is within the right of states to send them away because of their specific plans. The line between legitimate and illegitimate reasons for rejection may be quite hard to draw in practice, and as with any legal principle, there will be hard cases when it comes to applying it. But the important point here is that Kant is not necessarily committed to the position that any ground for rejection will do.

\section{Justification}

Kant grounds cosmopolitan law in the "original community of the land', that is in the idea that before any particular acquisition of property, the earth is in common possession. After such acquisition, others no longer have a rightful claim to use or occupy what is mine, 
and in the case of national territory this means that when a people has a rightful claim to the use and property of their land, foreigners do not, except when expressly permitted. But all parts of the earth, Kant says, continue to be thought of as parts of the whole to which everyone had an original right. This, he claims, implies that all nations stand in a community of possible physical interaction ( $M M$ 6: 352).

This argument provides at best a partial grounding for cosmopolitan law, however. The original community of the land may ground a right to be in those parts that do not belong to anyone yet, and the status of unclaimed spaces is indeed an important issue covered by cosmopolitan law. In Perpetual Peace, for example, Kant says that ships and camels may make it possible for humans from different parts of the earth to 'approach each other over these ownerless areas, and to utilize as a means of social interaction that right to the surface, which the human race holds in common' (PP 8: 358).

But Kant alsa thinks that the original community of the land somehow grounds the validity of cosmopolitan law in areas that are acquired. Yet his argument is terse and its structure is not immediately clear. For what exactly is the relevance of the idea of an original common possession of land? In his 1798 commentary to Kant's Doctrine of Right, Johann Heinrich Tieftrunk attempts to explicate what remains implicit in Kant's brief justification of cosmopolitan law.

On Tieftrunk's reconstruction, the fact that the earth must be thought of as originally in common possession means that even though it is divided up into parcels of land which have become private property, everyone must regard land owned by others as in principle acquirable. To deny a person the right to acquire any property from anyone else means as much as to say

You are not a human being at all, you have originally no equal right to be on the earth with others, you are not in original common possession of the entire soil and its things... You are a being which is not even entitled to the thought that something that I have could become yours. ${ }^{15}$

Tieftrunk argues that the hospitality right follows from the fact that the condition of the possibility of such acquisition is interaction, and the condition of the possibility of interaction is that one is allowed to present oneself to initiate interaction. ${ }^{16}$

Even if Kant were to endorse this reconstruction, however, it still does not suffice to ground cosmopolitan law to the full extent. For in 
interpreting the right to hospitality as the right to try to acquire other people's property, regardless of mational borders, Tieftrunk provides a justification for only part of what is covered under cosmopolitan law. If all attempts at cosmopolitan interaction would have to be seen as attempts to start negotiations about property transactions, not even the cases mentioned by Kant himself, such as shipwreck victims washed ashore and sailors seeking a safe haven from a storm, would be covered. Thus, we need a further account of why strangers have a right not to be treated with hostility upon their arrival on foreign territory.

Kant could have developed such an account straight from the original, innate human right to freedom, however. ${ }^{17}$ This is a right that is not acquired but belongs to every human being by birth alone. It is the right to 'freedom (independence from the coercive choice of another, in so far as it can coexist with the freedom of every other in accordance with a universal law' (MM 6: 237). It includes 'innate equality, that is the independence from being bound by others to more than one can in turn bind them' (MM 6: 237). This innate right to freedom applies to what is 'internally mine or yours', that is, a person's mental and physical faculties in so far as these can be influenced by others ( $M M$ 6:238). The innate right to freedom also includes, as Kant mentions elsewhere in the Metaphysics of Morals, the 'right to be there where nature or chance (without [one's] will) has placed [one]' (MM 6: 262). In the unpublished draft for the Doctrine of Right Kant motivates this by saying that being on land is necessary for the very existence of human beings, and thus, that people have a right to be on the land on which they are placed through no choice of their own, since denying them this right would mean denying them their existence and their freedom $(23: 318) .{ }^{18}$

The innate human right to freedom is all one needs to back up the principle of hospitality. For this right implies precisely the two aspects central to Kant's understanding of the hospitality principle: that prospective visitors have no right to intrude into the sphere of freedom of athers against their will, and that neither states nor individuals have the right to refuse visitors when this would lead to the annihilation of their freedom (their destruction).

Further support for the claim that Kant's doctrine of cosmopolitan law is best grounded on his notion of the innate right to freedom can be found in the comments that he makes in the section in which he introduces this right. Here Kant says it implies the right 'to do to 
others anything that does not in itself diminish what is theirs, so long as they do not want to accept it' (MM 6: 238). As an example, be mentions communicating one's thoughts to others. It is up to them whether to accept what is being said, thereby perhaps incurring false beliefs. By extension, one can derive a right to present oneself to others and request entry, interaction, exchange, etc., which still leaves the addressees at liberty to refuse the request. One does not diminish their freedom by trying.

A special problem is posed by the fact that granting refugee status to a person seems to entitle him or her to deprive others of their external property rights, against their will. The stranger's staying on land owned by others seems to 'diminish what is theirs'. After all, to own an object means that one is wronged if one is disturbed in the use of the object by someone else, regardless of whether one physically holds the object (cf. MM 6: 245-57). Therefore, the injunction to let the stranger use a piece of land, even if it is as small as the space needed for a body, seems an infringement upon the property rights of its owners. In this way, a conflict would seem to emerge between claims founded on the innate right to freedom and claims founded on property rights, thus showing Kant's doctrine of cosmopolitan law to be inconsistent with his theory of private law.

One could of course try to solve this problem by pointing out that foreigners do not acquire any property when they are entitled to the temporary enjoyment of other people's property, say, of a foreign harbour in a storm, or a shore on which they are shipwrecked. Also, Kant does not say that the visitors must be given any goods, such as food, for free. While both points are true, however, they do not fully address the problem, because they do not solve the difficulty that foreigners still interfere with the right of the property owner to determine how and by whom the property is used.

I would like to argue, however, that the requirements of cosmopolitan law and the principles of private law can be reconciled. In his discussion of constitutional law, Kant mentions a case that is in some interesting respects analogous to the case at hand. He argues that a government has the right to impose taxes on the people in order to provide for the poor and for foundling homes ( $M M$ 6: 326). He justifies this by saying that the state is founded on the general will of the people (as a rational idea, not an empirical reality), and that the people unite themselves into a commonwealth under the rule of law in order to ensure that those members of society who are not able to 
maintain themselves will be maintained with the help of the state. Therefore, the state has a right to tax the wealthy (who themselves benefit from the protection of the state, tool on behalf of the sustenance of their co-citizens.

In cosmopolitan law, 'individuals and states, who stand in an external relationship of mutual influence, are regarded as citizens of a universal state of humankind' (see above, p.74). This makes it possible to draw an analogy between the justification of the imposition of taxes by the state and that of the legal requirement to let foreigners use parts of one's territory in the case here at issue. Those who own territory on which foreigners arrive due to forces beyond their control can then be required under cosmopolitan law to let foreigners use part of their property if this is necessary for their survival. Obviously, in his discussion of taxation Kant goes much further than in his defence of the right to a safe haven. He does not ask for a world-wide taxation system or argue that there is a legal requirement to give up part of one's property for the benefit of strangers, but only implies that they should be able to use it temporarily, if this is necessary for their continued existence. But for present purposes what is important is that Kant does envision at least one other situation in which property owners are legally obliged to give up some rights to their property in order to provide for the sustenance of someone whose existence would be endangered otherwise.

\section{The Problem of Institutionalization}

Kant says virtually nothing about the institutionalization of cosmopolitan law. There are two questions here. The first question is what form coercion could take. This is important because Kant sees Recht (rights, rightful law) and the use of necessary coercion as two sides of the same coin (MM 6: 231-2). The lack of enforcement possibilities would seem to put the very designation Recht Weltburgerrecht (cosmopolitan law) at peril. The second question concerns what cosmopolitan citizenship consists in, particularly, whether humans and states can self-legislate cosmopolitan law. It seems that they would have to have a hand in framing cosmopolitan law in some way, if Kant is to avoid paternalism. Both questions point to the problem that either cosmopolitan law is not public law in any literal sense, or Kant must be sneaking in some kind of world 
republicanism. Given that Kant barely addresses these issues, to answer these questions involves going beyond Kant's own writings. But I will show that one can develop a modified Kantian account on the basis of his own principles. I begin with the problem of coercion.

\section{Coercion}

As it stands, Kant's theory provides no way of solving the problem of enforcenent and coercion. He rejects the very possibility of transnational enforcement of international law, which makes it impossible to draw on his discussion of international law in order to solve the problem of the enforcement of cosmopolitan law. Moreover, the section on the 'spirit of trade', which he calls the 'guarantee' of cosmopolitan law (PP 8: 365), provides no solution. Briefly put, his argument there goes as follows. Monetary greed will encourage states to promote peace, since trade makes money, making money is in the mutual interest of all states, and peace is more hospitable to trade than war. Promoting peace requires negotiations, which means international interaction, which is what cosmopolitan law is all about (PP 8: 368).

This is no real solution, however, since there is nothing in the pursuit of commercial gain as such that implies that hospitality rights for all humans (not just sales representatives, but also philosophers, tourists, refugees, and orhers) will be the inevitable spin-off. The interaction berween the United States and the People's Republic of China provides a current example. China does not let all of its citizens travel abroad freely, which means that the cosmopolitan rights of many are violated. But neither on the US side nor on the Chinese side is the spirit of trade sufficient to change this situation. Nor does it prevent China from treating non-commercial foreign visitors hostilely (as some say happened during the recent United Nations conference on the status of women). Nor did the spirit of trade protect North Korean refugees from being sent back by China to face a certain death. Mutual commercial interests do seem to provide an incentive to the US and China to preserve peace and commercial interaction. But it does not do enough to guarantee hospitality rights for everyone. Thus, other mechanisms than trade are needed to guarantee cosmopolitan rights universally.

If one wants to take cosmopolitan law literally as public law, taking seriously the designation 'right' in 'cosmopolitan rights' and assuming that rights and the possibility of coercion belong together, one 
must reject Kant's claim that transnational enforcement is neither desirable nor possible. But this claim of Kant's has a problematic status in light of his general theory that rights and coercion belong together, and thus, rejecting it allows for a more consistent Kantian position. Several authors have recently shown that Kant's position on the institutionalization of international law is inconsistent and unnecessary, and that his own principles should have led him to advocate the formation of a transnational body of states with limited coercive powers. ${ }^{19}$ Moreover, Kant's quite uncharacteristic claim that we should opt for a loose confederation of states because states will never want to join a transnational body with coercive powers (PP 8: 357 ) has to a large extent been falsified by twentieth-century developments.

To say that Kant's theory is compatible with enforcement of cosmopolitan law is not yet to specify what form a transnational body should take that guarantees cosmopolitan rights, and this, then, is the next question. I do not answer this question in full, but I point to one possible answer, suggested by twentieth-century history.

Traditionally, individuals appear as the subjects of rights in international law only in so far as they are citizens of states, that is, in virtue of their nationality. In the case of disputes, individuals must appeal for protection to a national legal order (either their own or a foreign one), without having access to transnational levels of appeals. Moreover, states were granted sovereignty and - as also laid down in the Charter of the United Nations - freedom from interference with their internal affairs. This gave state sovereigns a pretext, if not authorization, to deal with their subjects as they saw fit. But in this century, in part in reaction to vast abuses of this principle, the status of individuals in international law has been strengthened. As Alfred Verdross and Bruno Simma put it:

The newest developments in international law have broken up the absolute subjection of people to the state. Not only does the content of an ever growing number of treaties in international law serve the interests of individual humans or certain groups, but individuals are also being elevated immediately to bearers of rights under international law, and they are put in a position to assert these rights at the level of international law thernselves. ${ }^{20}$

These new rights are not tied to a particular nationality on the part of the individual. The improved legal status of refugees can serve as an example. Central to the treaties resulting from the 1951 Geneva 
convention ${ }^{21}$ is the prohibition against refusing or deporting refugees if that endangers them for reasons of their religion, tace, political views, or membership in a certain social group. It does not apply to endangerment in the form of hunger and poverty or disease, nor does it extend to a positive right to receive asylum; one can request asylum, but the decision is still left to the sovereign states. Nevertheless, persons endangered for any of the reasons first mentioned are legally protected regardless of their nationality.

Individuals not only have new rights, but can also be held responsible for crimes under international law, even when their actions are legal within their own state and their state has not signed treaties excluding such behaviour. Examples are the delicta iuris gentitum, such as slave trade, genocide, terrorism, many of which have been the subject of treaties since the $1970 \mathrm{~s} .{ }^{22}$ In many cases, individual states are authorized by international law to try persons who are accused of such crimes. In other cases, international tribunals provide some means of implementation. So far, such tribunals have been instituted ad boc, but proposals for a permanent international criminal court are being discussed. Although effectiveness and consistency of its enforcement leave much to be desired, it is important to realize that in such cases international law cuts through the shield of state sovereignty, creating a new level of legal responsibility for indjviduals.

This is a significant shift in the paradigm of international law. From being limited to regulating the relations between Christian sovereigns, its scope was broadened until it included all states, and then further to include international organizations such as the Red Cross. The fact that now individual human beings are designated as subjects of international law is another big step. In effect, international law now includes the category of rights that Kant subsumed under the title of cosmopolitan law.

International law has in some respects broadened the scope of individual rights beyond the 'limits' Kant set for cosmopolitan law in the third definitive article in Perpetual Peace. But many of these newer developments are compatible with his views. For example, as I indicated earlier, one can derive a strong notion of refugee rights from Kant's writings. Moreover, the 'limits' he set were meant to limit the rights of colonial powers rather than the further development of individual rights.

Enforcement is currently limited and inconsistent, but it exists. It is affected by the unequal distribution of money and power between 
states, in a way that Kant failed to foresee. The institutionalization and implementation of cosmopolitan law ultimately depend on states, and differences in their power and money influence their willingness to work together and pay the expenses of the institution. Thus, there are no guarantees that the developments mentioned will continue, and the fate of cosmopolitan law depends largely on whether its implementation coincides with the interests of the powers that be.

But what is important here is that in practice it has become possible to distinguish, in addition to legal agreements regarding states and their citizens, other agreements that invest individuals as individuals with rights and responsibilities. If one wanted to recognize this change by giving the second kind its own name, the term 'cosmopolitan law' would be quite proper.

\section{Citizenship}

There is reason to think that even under cosmopolitan law, states have fuller citizenship status than individuals. After all, in the absence of a world government, only states and international organizations sign agreements, and it is their representatives who negotiate the terms, not individuals qua individuals. ${ }^{23}$ But the notion of cosmopolitan citizenship of individuals gains more substance when one realizes that in democracies, individuals can co-legislate indirectly, by electing representatives who do so directly. In a parallel fashion, one can conceive of cosmopolitan law as indirectly democratic, and the term 'citizen' in 'world citizen' does not have to be read merely metaphorically, if those who determine cosmopolitan law are democratically elected representatives who are ultimately accountable to their constituents.

Moreover, individuals can exercise citizenship through engaging in public deliberation in a global network of overlapping public spheres. Kant recognizes the world historical importance of the fact that a violation of human rights in one place is 'felt in every place on earth' (PP 8: 360). He also sees a tight connection between citizenship and public deliberation. ${ }^{24}$ This invites us to develop his views on the public sphere a little further than he did himself, and apply them to the cosmopolitan level. ${ }^{25}$

More advanced means of communication provide the material conditions for a global public sphere. There is world-wide political, scientific, and cultural interaction, ranging from internet groups to large-scale United Nations conferences, to scholariy and scientific cooperation. Forums such as these, combined with a hospitable culture 
at the national level, can form the cultural seedbed for transnational political initiatives supporting cosmopolitan rights.

Again, there is no guarantee. While some barriers get broken down, others become more prominent. The existing economic and political inequalities between rich and poor, both within states and between states, still form a massive obstacle to the realization of equal cosmopolitan citizenship of all. For example, the internet is wonderful for allowing people far apart to get in touch and exchange information and ideas. But if the infrastructure in one's country does not support it, one cannot afford a computer, is illiterate, or does not speak the dominant language, one is now further behind than before.

This example should also serve to warn against easy equations of market globalization with a global increase in cosmopolitan citizenship. The global spread of capitalism and its products, say, a US-based hamburger chain, does not per se lead to an increased realization of cosmopolitan rights of individual human beings. ${ }^{26}$ What is necessary for the realization of cosmopolitan rights are not so much economic, but political initiatives and guarantees.

But one does not need a world state, in the sense of a single political state absorbing all currently existing states, in order to conceive of the possibility of the realization of cosmopolitan law to some degree. Less radical forms of transnational institutions can also give meaning to refugee rights. Thus, we should not be more pessimistic than the current state of the world forces us to be. Given the legal changes made in this century - often prompted, it must be said, by horrendous crimes - we can still say, with Kant, that 'the idea of a cosmopolitan law is not fantastic and overstrained' (PP 8: 360), because it is possible to give a Kantian account of the institutionalization of cosmopolitan law, at least to a degree.

In this paper I have argued that Kant's category of cosmopolitan law is neither superfluous nor metaphorical and that it is an appropriate category for conceptualizing the changes that have taken place within international law regarding the status of persons. Thus, the importance of cosmopolitan law, both within Kant's political theory and as a theme in the current discussion about cosmopolitanism, should no longer be underestimated.

Kant is a cosmopolitan of a moderate cast. His view is considerably less radical than proposals to overthrow the nation-state system, and 
his concept of cosmopolitan law, when taken in isolation from the rest of his political philosophy, is compatible with a tange of views regarding what political bodies the world should contain. It is compatible with different views on this issue, as long as they provide for a level of public law at which humans have certain basic human rights as 'citizens of the world', rather than as members of any particular lower-level political body.

Yet, even this moderate cosmopolitanism is quite radical. How to institutionalize cosmopolitan rights fully in a world in which economic, political, and other inequalities make it impossible to guarantee their protection is a difficult question. I do not claim to have answered this question here, but I have shown that it is at least not impossible to conceive of an institutionalization to some degree. ${ }^{27}$

\section{Notes}

Page references are to Kants Gesammeite Schriften, edited under the auspices of the Königliche Preussische Akademie der Wissenschaften (Berlin: Walter de Gruyter, 1902- ). All translations are my own. Abbreviations used: $M M=$ Metaphysics of Morals; $P P=$ Perpetual Peace; $T P=$ 'On the common saying: "This may be true in theory, but it does not apply in practice".

1 See, for example, Jürgen Habermas, 'Kant's idea of perpetual peace, with the benefit of two hundred years' hindsight', in James Bohman and Matthias Lutz-Bachmann (eds.), Perpetual Peace: Essays on Kant's Cosmopolitan Ideal (Cambridge, MA: MIT Press, 1997), pp.113-53; Howard Williams, International Relations and the Limits of Political Theory (New York: St. Martin's Press, 1996), esp. ch.9; David Held, Demacracy and the Global Order: From the Modern State to Cosmopolitan Governance (Stanford: Stanford University Press, 1995). Martha C. Nussbaum has drawn on Kant's moral theory for a moral version of cosmopolitanism. See 'Patriotism and cosmopolitanism', in Joshua Cohen (ed.), For Love of Country: Debating the Limits of Patriotism (Boston: Beacon Press, 1996), pp.3-17, and see her article, 'Kant and cosmopolitanism', in Bohman and Lutz-Bachmann (eds.), Perpetual Peace, pp.25-57. In this paper, I discuss not Kant's moral but his political cosmopolitanism. For a version of moral cosmopolitanism (in the Kantian tradition) with political implications, see Thomas W. Pogge, 'Cosmopolitanism and sovereignty', Ethics, 103 (1992), 48-75.

2 In his insightful book on democracy and globalization, David Held mentions the change in the starus of individuals in international law, but 
he does so merely in order to show that the sovereignty of states is being contested. He discusses Kant's notion of cosmopolitan law brielly but not its ramifications for the status of individuals as such. Instead, for Held, the 'cosmopolitan community' is 'a community of all democratic communities' (Democracy and the Global Order, p.232). In contrast to many interpretations of human rights as moral rights, Habermas emphasizes that they are inherently legal in nature, and orientated to becoming legal rights if they have not become such already. Thus, he shares Kant's individualist commitment, and he explicates this position in part with reference to Kant. But Habermas does not consider the current status of individuals under international law and only discusses Kant's account of a 'cosmopolitan situation' in the early sense, mentioned in 0.4 below (Habermas, 'Kant's idea of perpetual peace').

3 From Francesco de Vitoria (1492/3-1546) on, free communication and trade were mentioned in the context of international law, i.e. as right of states and their citizens against other states. Kant seems to be the first to introduce it as a separate, third category of public law.

4 In this essay, I focus on Kant's position in Perpetual Peace and the Metaphysics of Morals. In earlier texts, Kant defends a league of states with coercive powers. In 'Idea for a universal history from a cosmopolitan point of view', Kant speaks of such a league as a 'great political body' in which every member state receives its security and rights from a 'united power and from decisions in accordance with the laws of a united will' (8: 24, 28; cf. also TP 8: 310-11). Although Kant calls this a 'cosmopolitan' state of affairs, only states, not individuals, are the 'citizens' in such a political system.

5 Reinhard Brandt shows that the third definitive article can be regarded as the systematic completion of the first and second. See Reinhard Brandt, 'Vom Weltbürgerrecht', in Otfried Höffe (ed.), Imunamuel Kant: Zum ewigen Frieden (Berlin: Akadenie Verlag, 1995), pp.133-48.

6 Georg Cavallar, Pax Kantiana: Systematisch-historische Untersuchung des Entumers 'Zum ewigen Frieden' (1795) von Immanuel Kant (Vienna: Böhlau, 1992), pp.235ff.

7 Wilhelm Traugort Krug, 'Aphorismen zur Philosophie des Rechts', in Anita Dietze and Walter Dietze (eds.), Eviger Friede? Dokumente einer deutschen Diskussion um 1800 (Leipzig: Kiepenheuer, 1989), pp.362-3.

8 The term 'universal state of humankind' should not be taken to imply that Kant advocates the establishment of a world state that would absorb existing states. It refers to the legal system which unites all humans under common, cosmopolitan law (cf. MM 6: 311).

9 The difference between Staat $(P P)$ and Volk $(M M)$ is not as great as it may seem to be. Kant explains, in $\$ 53$ of the Metaphysics of Morals, that the term Volk can be used 'in the legal sense' as natio. It then refers to a 
people born within the same republican state, who, as citizens, form something like a family (MM 6:343).

10 On a terminological note, Kant might have wished to draw a distinction between active and passive world citizens analogous to the distinction in MM \$46. Children, who do not yet have the requisite cognitive capacities to be active citizens, would then be passive world citizens until they reach maturity and advance to active world citizenship. In MM and TP Kant infamously and inconsistently also excludes women and 'dependent' workers from active citizenship. Even if Kant extended this exclusion to the cosmopolitan level, this would not entail that active and passive world citizens would be treated differently at the border. Although 'passive world citizens' would be excluded from woting, both classes of world citizens would be equally protected by the law. Therefore, I use genderinclusive language in the examples in my discussion of the content and justification of cosmopolitan law. See also my article, "The problematic status of gender-neutral language in the history of philosophy: the case of Kant', Philosophical Forum, 25 (1993), 134-50.

11 In her translation of the Metaphysics of Morals, Mary Gregor transiates Verkehr as 'commerce', which is correct but ambiguous, since it could also be read narrowly as referring to business only.

i2 Kant's position is bere diametrically opposed to Vitoria's, who argued that the Spanish war against the American Indians was justified, because they should not have denied the Spanish the right to enter their territory. See Francisco de Vitoria, De Indis, Q.3, de tit. leg., art.1, in Francisco de Vitoria, Political Writings, ed. Anthony Pagden and Jeremy Lawrance (Cambridge: Cambridge University Press, 1991), p. 278.

13 See also Howard Williams, Kant's Political Philosophy (Oxford: Blackwell, 1983), p.260.

14 On refugee rights, see Guy S. Goodwin-Gill, The Refugee in International Law, 2nd edn. (Oxford: Clarendon, 1996).

is Johann Heinrich Tieftrunk, Pbilosophische Untersuchungen über das Privat-und das öffentliche Recht zur Erläuterung und Beurtheilung der metaphysischen Anfangsgründe der Rechtslehre vom Herrn Prof. Inim. Kant (Halle: Rengersche Buchhandlung, 1798), vol.2, pp.576-7.

16 lbid., pp. $575-7$.

17 I here develop a suggestion made by Jürgen Habermas, in 'Kant's idea of perpetual peace', pp. 128-9.

18 See, on Kant's doctrine of the innate right to freedom, Leslie Arthur Mulholland, Kant's System of Rights (New York: Columbia University Press, 1990), pp.199-231. On the right to be on land as innate right, see, pp. 218-20.

19 Matthias Lutz-Bachmann, 'Kant's idea of peace and the philosophical conception of a world republic', in Perpetual Peace, pp.59-77; Otfried 
Höffe, 'Kant als Theoretiker der internationalen Rechtsgemeinschaft', in Gerhard Schönrich and Yasushi Kato (eds.), Kant in der Diskussion der Moderne (Frankfurt: Suhrkamp, 1996), pp.489-505; Sharon Byrd, 'The state as a "moral person", , in Hoke Robinson (ed.), Proceedings of the Eighth International Kant Congress, Memphis 1995 (Milwaukee: Marquette University Press, 1995), pp.171-89.

20 Alfred Verdross and Bruno Simma, Unverselles Völkerrecht: Theorie und Praxis, 3rd edn. (Berlin: Duncker \& Humblot, 1984), p.38. Translation mine. See also Malcolm N. Shaty, International Law (Cambridge: Cambridge University Press, 1991), pp.178-81.

i) 28 July 1951. United Nations Treaty Series, vol.189, pp.150ff. This was not the first treaty on the status of refugees, but the result of a development that started in the early decades of this century. See Verdross and Simma, Universelles Völkerrecht, pp.839-40.

22 Verdross and Simma, Universelles Völkerrecht, pp.260-7.

23 This does not make the category obsolete, since that was developed in rerms of the bearers of rights.

24 CE. 'What is enlightenment?' and TP part 2.

25 C. also James Bohman, 'The public spheres of the world citizen', in Proceedings of the Eighth International Kant Congress, pp.1065-80.

26. In fact, as Benjamin Barber points out, is may very well lead to vehement reactions in the form of 'factitious patriotism' and dangerous antiuniversalism. See Benjamin R. Barber, Jihad us. McWorld (New York: Times Books, 1995). See also the discussion of the role Kant attributes to the 'spirit of trade'.

27 I would like to thank Joel Anderson, Ciaran Cronin, Larry May, Thomas McCarthy, Thomas Pogge, Carl Wellman, and two anonymous referees for helpful comments. Earlier versions of this essay were presented at the 1996 conference on the 'Metaphysics of Morals' at Smith College, organized by Sharon Byrd, Jan Joerden, and Joachim Hruschika, and as the 1997 meeting of the Central Division of the APA. I would like to thank the participants in both meetings for many helpful comments and suggestions. 